\title{
Arrangement and Dynamication of Family Law Updating in Indonesia
}

\section{Ike Yulisa, Muhamad Yusuf, Doli Witro, Luqyana Azmiya Putri, Mhd. Rasidin, and Nurul Alamin UIN Iman Bonjol dan IAIN Kerinci}

Email: doliwitro01@gmail.com

\begin{abstract}
In Indonesia, family law is well regulated in law or government regulations. In this case, with the increasingly complex family law issues supported by divorce rates, which reached 398,245 in 2015 , then in 2017 , it increased to 415,898 , and with the development of science and technology, so many problems arise both in terms of muamalah or family law itself. For this reason, structuring is needed through legal reform that makes it follow what is needed by the wider community. Starting from this, this paper will discuss the arrangement of Islamic family law and the dynamics of family law reform in Indonesia. This study aims to provide an overview of the arrangement of Islamic families and Islamic family law reform in Indonesia. This paper uses qualitative research methods that are library researching. The data in this article was obtained from books, journals, articles, magazines related to the structure and dynamics of family law reforms in Indonesia. After the data is collected, the writer analyzes with data analysis techniques, namely data reduction, data presentation, and concluding. The results of the study show that the structure and dynamics of family law in Indonesia, when viewed in the context of Islamic law reform, reveal a unique and problematic portrait of reform. It is said so because Indonesia applies three legal systems, namely customary law, Islamic law, and Western law.
\end{abstract}

Keywords: Arrangement, Dynamication, Family Law of Indonesia

\begin{tabular}{l} 
Abstrak \\
\hline Hukum keluarga telah diatur dengan baik dalam undang-undang ataupun dalam \\
peraturan pemerintah. Dalam hal ini dengan adanya permasalahan hukum \\
keluarga yang semakin kompleks yang didukung oleh angka perceraian yang pada \\
2015 mencapai 398.245, kemudian pada 2017 meningkat menjadi 415.898 serta \\
dengan adanya perkembangan ilmu pengetahuan dan teknologi, sehingga banyak \\
timbul permasalahan baik dari segi muamalah ataupun hukum keluarga itu \\
sendiri. Untuk itu diperlukan penataan melalui pembaruan hukum yang \\
menjadikannya sesuai dengan apa yang dibutuhkan oleh masyarakat luas. \\
Berangkat dari hal tersebut, tulisan ini akan membahas mengenai penataan hukum \\
keluarga Islam dan dinamisasi pembaharuan hukum keluarga di Indonesia. Kajian \\
ini bertujuan untuk memberikan gambaran tentang penataan keluarga Islam dan \\
pembaruan hukum keluarga Islam di Indonesia. Tulisan ini menggunakan metode \\
penelitian kualitatif yang bersifat penelitian pustaka (library research). Data-data
\end{tabular}


dalam artikel ini diperoleh dari buku-buku, jurnal-jurnal, artikel-artikel, majalahmajalah yang berkaitan dengan penataan dan dinamisasi pembaharuan hukum keluarga di Indonesia. Setelah data-data terkumpulkan penulis menganalisis dengan teknik analisis data yaitu reduksi data, penyajian data, dan penarikan kesimpulan. Hasil penelitian menunjukkan penataan dan dinamisasi hukum keluarga di Indonesia bila dilihat dalam konteks pembaruan hukum Islam, menampakkan potret pembaruan yang unik sekaligus problematik. Dikatakan demikian karena di Indonesia berlaku tiga sistem hukum yaitu Hukum Adat, Hukum Islam dan Hukum Barat.

Kata Kunci: Penataan, Dinamisasi, Hukum Keluarga Indonesia

\section{A. Introduction}

Humans in fulfilling their rights and obligations towards fellow members of the community, of course, can not be separated from the bonds of dependence on each other. The bonds of dependentness, such as mutual help, help each other receive or provide services between each other, and also relate to others to meet the needs in life. Therefore it is essential for one coaching. ${ }^{1}$

Islam attachs great importance to person and family coaching. The nobleness of morals in the person and families will create a harmonious society. Therefore, family law occupies a strategic position in Islamic law. Construction the law for individuals and families is closely related to the religious awareness and obedience of every Muslim. ${ }^{2}$ Islamic family law always attracts attention to be discussed from time to time. In Indonesia, family law is well regulated in law or government regulations. In this case, with the increasingly complex family law issues supported by divorce rates, which reached 398,245 in 2015 , then in 2017 , it increased to $415,898^{3}$, and with the development of science and technology, so many problems arise both in terms of muamalah or family law itself. For this reason, structuring is

\footnotetext{
${ }^{1}$ Doli Witro, "Praktek Jual Beli Parang dengan Cara Penumpukan untuk Meningkatkan Harga di Desa Koto Padang Perspektif Hukum Islam", Al-Qisthu, Vol. 17, No. 1, 2019, p. 34-35.

${ }^{2}$ Budiman Sulaeman, "Asas - Asas Hukum Keluarga dalam Kompilasi Hukum Islam (Membedah Pasal - Pasal KHI)", Jurnal Hukum Diktum, Vol. 9, No. 2, 2011, p. 150.

${ }^{3}$ Doli Witro, "Kelompok Wanita Tani (KWT) Pelangi Kopi Sebagai Inovasi Pemberdayaan Janda Guna Mengentaskan Kemiskinan di Desa Giri Mulyo", Komunitas: Jurnal Pengembangan Masyarakat Islam, Vol. 10, No. 2, 2019, p. 94.
} 
needed through legal reform that makes it follow what is needed by the wider community.

Although the renewal of Islamic law is seen as a necessity, it must be emphasized that the renewal of Islamic law, which includes all forms of muamalah is permitted by Islamic sharia, as long as it is not counter-productive to the soul and spirit of Islamic law itself. It is said so because Islamic law in the field of muamalah only regulates and establishes its main principles in general, while the details are left to humans to think about, provided they continue to depart from the basic principles desired by Islamic law itself. In this case, it can be said that the soul and principles of Islamic law are constant, permanent, stable, and do not change over time. However, the legal, technical, and branch events can undergo changes and renewal following the demands of the times. ${ }^{4}$

Family law, in general, can be interpreted as a law governing family ties. This kinship can occur because of blood ties, or it can occur because of a marriage. "This family relationship is significant because it is related to the relationship between parent and child"5, inheritance law, guardianship, and trust. Family law is defined as the overall rules that govern family relations. The purpose of kinship here is of two kinds, namely the first in terms of blood relations and the second in terms of marital relationships. Kinship, in terms of blood relations or can be called kinship, is a family relationship that exists between several people who have the same ancestor. Kinship due to marriage is a family relationship that occurs because

${ }^{4}$ A. Intan Cahyani, "Pembaharuan Hukum Dalam Kompilasi Hukum Islam", ad-Daulah, Vol. 5, No. 2, 2016, p. 302-303.

${ }^{5}$ Doli Witro, "Islamic Religious Education In The Family To Strengthen National Resilience Of Surah At-Tahrim Verse 6 Perspective", Al-Muaddib :Jurnal Ilmu-Ilmu Sosial dan Keislaman, Vol. 4, No. 2, 2019, p. 307. See too, Muhamad Yusuf dkk, "Digital Parenting to Children Using The Internet". Pedagogik Journal of Islamic Elementary School, Vol. 3, No. 1, 2020, p. 6. See too, Yessy Gusminalita, Doli Witro, and Kesi Afrilia, "Education Child In A Family Of Surah An-Nisa’ Verse 9 Perspective”, PIONIR: Jurnal Pendidikan, Vol. 9, No. 1, 2020. 
of a marriage between a person and a family that is not blood-related by his wife (husband). ${ }^{6}$

Starting from the description above, this paper will discuss the arrangement of Islamic family law and the dynamics of family law reform in Indonesia. This study aims to provide an overview of the arrangement of Islamic families and Islamic family law reform in Indonesia. It is therefore expected to make the public understand the importance of structuring family laws in a country.

\section{B. Research Methods}

This article uses qualitative research methods that are library research. The data in this article was obtained from books, journals, articles, magazines related to the structure and dynamics of family law reforms in Indonesia. After the data is collected, the writer examines and understands the data related to the problem being studied to obtain the data sought and outlined in this article. Then after that, the authors analyze the data analysis techniques revealed by Miles and Huberman, namely "data reduction, data presentation, and concluding".

\section{Discussion}

\section{Arrangement of Family Law in Indonesia}

Islamic family law sticking to the surface stems from the recognition Pengadilan Agama ${ }^{8}$ (PA) officially as one of the executor's "judicial power" in the rule of law through Article 10 of Law Number 14 of 1970. Furthermore, the position, authority, and organization have been regulated and elaborated in Law Number 7 of 1989, Law Number 3 of 2006 which has the authority to adjudicate certain cases: 1) marriage; 2) inheritance; 3) wills; 4) grants; 5) endowments; 6)

\footnotetext{
${ }^{6}$ Eko Setiawan, "Dinamika Pembaharuan Hukum Keluarga Islam di Indonesia", De Jure: Jurnal Syariah dan Hukum, Vol. 6, No. 2, 2014, p. 139-140.

${ }^{7}$ Matthew B. Miles and A. Michael Huberman, Qualitative Data Analysis (a Source book of New Methods), (Beverly Hills: Sage Publications, 1984), p. 21-24.

${ }^{8}$ Next sentence Pengadilan Agama in this article abbreviated with words PA only.
} 
infaq; 7) shadaqah; 8) zakat; and 9) sharia economics, for Muslim residents ${ }^{9}$. The fact that the existence of the PA has not been accompanied by a comprehensive set of positive legal tools or means and applies unification as a reference. Although the material law, which becomes the jurisdiction of the religious court, has been codified in Law Number 1 of 1974 and Government Regulation Number 9 of 1975, basically, the matters stipulated therein are the main points. As a result, judges who are supposed to refer to the law, then refer to the doctrine of the science of fiqh. Therefore, differences in legal decisions between the PA's on the same issue are something that is understandable. ${ }^{10}$

Islamic family law contained in a variety of legal rules, when examined indepth, still contains many weaknesses as a logical consequence of the dynamics of life. Moreover, when faced with the needs and complexity of current society's problems, efforts must be made to actualize them or renewal, such as the strengthening of currents requiring equality between men and women or removing gender-biased laws that tend to put women in subordinate positions. ${ }^{11}$ The assumption that needs to be built is that the unification of Islamic law is still needed for public benefit. The basis of usul fiqh used is ma layudraku kulluhu layutraku kulluhu. Do not throw away something because you cannot achieve a truly perfect whole. Absolute perfection exists only with Allah. In historical records in Indonesia, the issue of renewing family law had emerged long before independence was achieved. At the time of the Women's Congress of 1928, this issue arose because of the many cases affecting women during marital life, such as underage marriages, forced marriages, polygamy, arbitrary divorce, and ignoring women's rights and so on. In 1937, the Dutch colonial government drafted a modern marriage law called the marriage registration ordinance. This step was

\footnotetext{
${ }^{9}$ Doli Witro, "Urgency Building Islamic Economic System In Indonesia Al-Quran Perspective", Jurnal Ekonomi Islam, Vol. 11, No. 1, 2020, p. 67.

${ }^{10}$ Cik Hasan Bisri, 1999, Kompilasi Hukum Islam dan Peradilan Agama dalam Sistem Hukum Nasional, Logos, Jakarta, p. 17.

${ }^{11}$ Eko Setiawan, op.Cit., p. 142.
} 
taken at the insistence of the women's organizations that existed at the time. The registration of this marriage applies to the indigenous population. Arabic and Asian are not Chinese, which are in Indonesia. Remarkably, this ordinance establishes monogamous rules and gives equal divorce rights to women and men. Even so, this ordinance is only applied to those who choose the registration rules for their marriage. $^{12}$

In 1950, the marriage law, which coordinated all interfaith and racial interests in Indonesia, had not yet been owned by this country. The marriage ordinance based on monogamy was rejected by the government of the Republic of Indonesia. Previously there was a law in the Republic of Indonesia Government of 1946, which stipulated marriage registration, suggested disapproval of child marriages and forced marriages, suggested that marriage officials advise married couples about their rights, and try to prevent divorce by examining the problems of both disputing parties (husband and wife). Nevertheless, in practice, both child and forced marriages still occur frequently. As a result, the insistence on a marriage law that guarantees equal rights for all citizens continues to roll until the formation of the marriage commission in 1950. The marriage commission consists of religious experts, the majority of whom are men, as well as female leaders from various backgrounds, including among Catholics and also Muslims. In the process, the commission succeeded in designing a marriage law that could be used by all Indonesian citizens. However, in the design, marriage is based on mutual liking for both partners, and polygamy is permitted on strict terms and only with the partner's religious agreement. There is an exciting thing that happens when the marriage commission arranges the period of the marriage law draft. ${ }^{13}$

\footnotetext{
${ }^{12}$ Holan Riadi, "Hukum Keluarga Islam di Indonesia dan Dinamikanya", Mukammil: Jurnal Kajian Keislaman, Vol. 1 No. 2, 2019, p. 130.

${ }^{13} \mathrm{Al}$ Fitri, Pembaruan Hukum Keluarga di Indonesia Melalui Kompilasi Hukum Islam, https://badilag.mahkamahagung.go.id/, accessed on 20 April 2020.
} 
The government at that time announced Decree Number 19 of 1952 concerning the Rules for Pension Benefits for widows of civil servants. One of the decisions made was that in the case of polygamy, the retirement benefits were given twice the amount received by an employee's "widow" to be shared equally with other wives with no more than four people. While for civil servants polymers, receive an additional salary. This means that polygamy is permitted and even supported by the state by using public money to pay the costs. This stipulation naturally reaps protests and demonstrations from a full circle of the women's movement who fight for women's rights. At that time, however, none of the Muslim women's organizations participated, due to the lack of freedom of their relations with some religious organizations led by men.

Thus the effort to reform the family law continued until 1974. By several figures in a public hearing with Dewan Perwakilan Rakyat (DPR) At that time, demands were made and the formation of laws governing marriage, which must regulate matters including: 1) the existence of an agreement from the prospective husband and wife to prevent forced marriage; 2) the stipulation of the minimum age for marriage because of the importance of family welfare in marriage; 3) marriages based on monogamy with very strict exceptions; 4) equal rights in filing for a divorce between husband and wife; and 5) fair share of shared property in the event of a divorce. With these demands, finally, the desired rules were established through Law Number 1 of 1974 concerning Marriage. However, laws are normative rules that govern human behavior patterns. ${ }^{14}$

Therefore, the law should not close itself to renewal efforts, according to the needs and mutual benefit. Moreover, ideally, a law must always uphold the basic principles of Islam and the value of human rights, such as justice, benefit (maslahah), pluralism (al-ta'addudiy), democracy (al-dimuqraty), and equality (al-

\footnotetext{
${ }^{14}$ Qodariah Barkah, "Kebijakan Kriminalisasi dalam Reformasi Hukum Keluarga di Indonesia”, Nurani, Vol. 17, No. 1, 2017, p. 17.
} 
musawah), especially equality between men and women ${ }^{15}$. Therefore, later demands for an amendment to Law Number 1 of 1974 concerning Marriage have returned to bloom. Not only in Indonesia, in various other Muslim countries also faced with the same demands, given the family law that applies in their country is still gender-biased and has not fulfilled the desire for shared justice. Not surprisingly, this family law reform effort has always been an issue of controversy in modern Muslim countries.

As a consequence, efforts to reform family law always face stiff resistance, especially from groups of religious authority owners, because changing family law is considered to change the essence of religion. Efforts to reform family law could be interpreted as defiance of Islamic law. As a result, not all Muslim-populated countries have renewed their family law until rolling in $1974 .{ }^{16}$ Arrangement of family law in Indonesia in addition to marriage in Law Number 1 of 1974 and Government Regulation Number 9 of 1975, also Kompilasi Hukum Islam (KHI) governing marital, inheritance and will matters, besides that there is also Law Number 41 of 2004 concerning endowments and so on. ${ }^{17}$

\section{Dynamication of Family Law Updating in Indonesia}

Islamic law, as religious law, comes from the revelations of God guided by Muslims. However, there is currently a phenomenon of "assimilation" between Islamic law and positive law in Muslim countries. As Islamic law is legalized as a national law, this phenomenon occurs in many Muslim countries, which have long applied the western legal system. "In a country where the majority of the

${ }^{15}$ Natardi, Ali Hamzah, dan Doli Witro, "Pemikiran Islam Kontemporer tentang Reposisi Kesetaraan Gender dalam Perspektif Al-Quran", AL-MAIYYAH: Media Transformasi Gender dalam Paradigma Sosial Keagamaan, Vol. 13, No. 1, 2020, p. 70.

${ }^{16}$ Eko Setiawan, io. Cit., p. 141-146.

${ }^{17}$ Doli Witro, Ike Yulisa, and Ali Hamzah, "Management of Productive Waqf In Islamic Boarding School Foundation Adlanyah Tampus Ujung Gading Lembah Melintang District", Mahkamah: Jurnal Kajian Hukum Islam, Vol. 5, No. 1, 2020, p. 93. 
population is Muslim"18, the aspiration to apply Islamic law as a national law is powerful, so that with the strategy of legalizing Islamic legal material in the form of legal drafting, it becomes a Rule of Law to be established as statutory law. The renewal of Islamic family law in Muslim countries continues to develop, starting from the beginning of the 20th century, especially related to marriage, divorce, and inheritance. This effort was started by Turkey (1917), then Lebanon (1919), Egypt (1920 and 1929), Jordan (1951), Syria (1953), and Tunisia were among the Muslim countries that experienced this phenomenon (1956) ${ }^{19}$. Until 1996, there were only five countries in the Middle East that had not yet renewed marriage law, namely the United Arab Emirates, Saudi Arabia, Qatar, Bahrain, and Oman. ${ }^{20}$

Munawir Syadzali is known as a figure who is very strong in encouraging the Muslim community to engage in honest and courageous ijtihad ${ }^{21}$. A well-known idea is about the need to change the law of inheritance, especially regarding the fairer and proportionate distribution of women. Indeed, when viewed from its objectives, the renewal of family law in general aims to improve the status of women in all aspects of life and family law, including inheritance. Although this purpose is not explicitly stated, the legal material formulated that the laws around family law are generally made respond to many demands on the status and position of women that are more just and equal. ${ }^{22}$

${ }^{18}$ Doli Witro, "Ulama and Umara in Government of Indonesia: a Review Relations of Religion and State", Addin, Vol. 14, No. 1, 2020. See too, Imaro Sidqi and Doli Witro, "Kedudukan Fatwa Majelis Ulama Indonesia (MUI) Dalam Perspektif Hukum Islam dan Nasional: Studi Implikasi Fatwa Terhadap Masyarakat", Nizham, Vol. 8, No. 1, 2020, p. 65.

${ }^{19}$ Lathifah Munawarah, "Politik Hukum Keluarga Islam di Tunisia", Jurnal Al- 'Adl, Vol. 12, No. 1, 2019, p. 78.

${ }^{20}$ Ratih Lusiani Bancin, "Hukum Keluarga Islam di Tunisia", Jurnal: Penelitian Medan Agama, Vol. 9, No. 2, 2018, p. 284-285.

${ }^{21}$ Munawir Sadzali in article Sulthan Syahril, "Munawir Syadzali (Sejarah Pemikiran Dan Kontribusinya Bagi Perkembangan Pemikiran Islam Indonesia Kontemporer)", Analisis, Vol. 11, No. 2, 2011, p. 222.

${ }^{22}$ Al Fitri, Pembaruan Hukum Keluarga di Indonesia Melalui Kompilasi Hukum Islam, https://badilag.mahkamahagung.go.id/, accessed on 20 April 2020. 
Another goal that Islamic countries have in renewing family law is legal unification. This law unification effort was carried out because the people adhered to various schools or even different religions. In Tunisia, for example, efforts to unify marriage law are aimed at all citizens regardless of religious differences. In addition to these goals, there are other objectives of efforts to renew family law, namely to respond to the demands of the times, where the demands of the times and the dynamics of the development of these societies are the result of global influences that affect almost all aspects of human life. In these family law reforms, efforts are generally focused on issues of personal status that are still governed by established Islamic law in several Muslim countries. To reduce the objections of conservatives, this renewal is often done indirectly through procedural channels. For example, the new law requires the requirement that marriage must be recorded in order to be legally valid and that the couple must have reached a certain minimum age, which is an attempt to obstruct early marriage and forced marriages. Concerning this issue, the idea of mujtahids emerged to carry out reforms in the law, especially in the case of muamalah, which concerns the interests of the people, in this case, also needed methods that are still relevant in terminating the law for the mujtahids. ${ }^{23}$

To find out about legal renewal, a renewal concept is needed first. In contemporary Islamic legal literature, the word renewal is used with the words reform, modernization, actualization, and so on. Various kinds of understanding of the new word and the reform above are accommodated in the terminology regarding changes in the law. ${ }^{24}$ Satjipto Rahardjo, for example, introduced the terminology on legal changes with legal reform, and even recently, according to Satjipto, the term 'legal modernization' was also used. ${ }^{25}$ Similar views expressed

\footnotetext{
${ }^{23}$ Eko Setiawan, op.Cit., p. 144.

${ }^{24}$ Ibid., p. 144-145.

${ }^{25}$ Satjipto Raharjo, 2009, Membangun dan Merombak Hukum Indonesia, Genta Publishing, Yogyakarta, p. 15.
} 
by Abdul Manan, according to him, the term is often used to refer to reform and reform, modernization, reactualization, deconstruction, reconstruction, tarjih, and tajdid. Of the several terms that are more appropriate to use is structuring the law so that it can adjust to changes in society. Among these words, the most widely used is the word reform. Reform comes from the English language "reformation", which means to form or reorganize. Reform is the same as renewing, the origin of a new word with the meaning of repairing so that it becomes new or replacing with a new one, or the process of action, how to renew, the process of developing customs, and a new way of life. ${ }^{26}$

From the concept of reform above, it can be understood that what is meant by the renewal of Islamic law is as an effort or act through a specific process with full sincerity carried out by those who have competence and authority in the development of Islamic law (mujtahid) in ways that have been determined based on the rules of istinbath law are justified to make Islamic law more fresh and modern. Efforts to re-actualize Islamic teachings in the field of law are part of efforts to reform Islamic law, especially in the context of modern times today. ${ }^{27}$

In the context of Islamic law renewal in family law in Indonesia, a unique and problematic portrait of reform is also revealed. It is said so because Indonesia applies three legal systems, namely customary law, Islamic law, and Western law. These three legal systems, according to Hooker, there is no single legal system that sets aside each other. On the other hand, the same degree of enactment of the three legal systems does not always run in the same direction. However, in certain situations and conditions, sometimes these three legal systems conflict. ${ }^{28}$ The third conflict with the prevailing legal system in Indonesia eventually gave rise to

${ }^{26}$ Abdul Manan, 2006, Reformasi Hukum Islam di Indonesia, Rajawali Pers, Jakarta, p. 145 .

${ }^{27}$ Amir Syarifuddin, 2005, Meretas Kebijakan Isu-isu Penting Hukum Islam Kontemporer di Indonesia, Ciputat Press, Jakarta, p. 38-39.

${ }^{28}$ Imam Syaukani, 2006, Rekonstruksi Epistemologi Hukum Islam dan Relevansinya dengan Pembangunan Hukum Nasional, Raja Grafindo Persada, Jakarta, p. 88. 
tension. The tension between the three has, in turn, become a severe problem in the renewal of Islamic law in family law in Indonesia, which is not single and independent. However, it is always configurative with the aspects that surround it.

Thus, the renewal of Islamic law in family law in Indonesia is not single and independent. However, it is always configurative with the aspects that surround it. Aspects related to the renewal of family law in Indonesia include:

\section{Material Aspects}

After the Indonesian people declared their independence on August 17, 1945, the renewal of legal material began. This was intended to replace the Dutch colonial inheritance law, which was contrary to the constitution of an independent Indonesian state. According to Hazairin, after the proclamation of Indonesian independence and the 1945 Constitution was made a State constitution, all the laws and regulations of the Dutch East Indies were no longer valid. ${ }^{29}$ The reality of Islamic law as a source of law in Indonesia places it in an existential position in the context of renewing family law material. At the very least, supported by two arguments, namely: First, Islamic family law is built on universal principles, so that it is possible to be translated substantively in the renewal of the Indonesian family law system. Second, the renewal of Islamic family law material in the family law system in Indonesia can be done by establishing Islamic family law material as legislation that applies positively.

\section{Methodological Aspects}

In the context of Islamic law reform, the methodological aspect is seen as a factor that determines the legal form (ijtihad result) carried out. Therefore, within the framework of Islamic family law reform in Indonesia that is in line with community legal awareness and following the characteristics of national law, several approaches can be used, namely:

a. Historical Approach

\footnotetext{
${ }^{29}$ Imam Syaukani, op.Cit., p. 81.
} 
The historical approach is intended to determine the historical background of a legal product. The application of the historical approach in the renewal of family law in Indonesia can be seen in the provisions of article 2 paragraph 2 of Law Number 1 of 1974 concerning Marriage and article 6 paragraphs 1 and 2 of KHI, which regulates the provisions on marriage registration. In the books of classical fiqh, no provisions regarding marriage registration are found. According to Ahmad Rofiq that there were no provisions for marriage registration in classical fiqh books because, at that time, the level of trust of the Muslims was still high, so the possibility of marriage abuse was relatively little. ${ }^{30}$

b. Maslahah Approach

The level of benefit of a formulation of Islamic family law reform in Indonesia should ideally be used as the spirit of every legal provision. Therefore, the provisions of marriage registration are seen as brilliant achievements of Islamic legal experts in Indonesia. ${ }^{31}$

c. Social Reality approach

The conceptual approach to social reality is interpreted as an effort to reform the law by presenting an approach to social reality and other approaches simultaneously in formulating (istinbat) law.

\section{Sociological Aspects}

In the context of legal reform, the sociological aspect that continues to experience development from time to time is seen as one of the aspects that accompany the process of legal reform. The sociological aspects that accompany Islamic law reform in family law in Indonesia include:

a. Kinship institutions function as meeting the needs of the maintenance and development of offspring (reproduction).

${ }^{30}$ Ahmad Rofiq, 1995, Pembaharuan Hukum Islam di Indonesia, Raja Grafindo Persada, Jakarta, p. 106-7.

${ }^{31}$ Imam Syaukani, op.Cit., p. 255. 
b. Educational institutions serve as meeting the needs in socializing the beliefs, values, and rules adopted by one generation to the next generation.

c. Scientific institutions function as the fulfillment of needs in developing an understanding of God's verses.

d. Political institutions serve as the fulfillment of the medium in carrying out a renewal of family law in Indonesia through political articulation in the life of society, nation, and state.

e. Legal institutions serve to provide juridical legitimacy of Islamic law reform in Indonesian family law. As it is known that the state constitution of the 1945 Constitution provides strong legitimacy for the renewal of Islamic family law to be established as national law. ${ }^{32}$

Since the last thirty years, there have been significant changes to Islamic law in Indonesia. Changes have occurred since the birth of Law Number 1 of 1974 concerning Marriage and Government Regulation Number 9 of 1975, which was then followed by the enactment of several other laws and regulations in the following years. The reforms that occur are updates related to family law in the field of figh, which is shifted to the new values mentioned in the laws and regulations and the decision of the Religious Courts. Changes in Islamic law had occurred in specific fields due to the values contained in fiqh that are no longer able to provide solutions to new problems when fiqh was written by the jurists the new problems had not yet occurred or did not yet exist. Examples are marriages whose consent is made by telephone, giving heirs to heirs of different religions from heirs, placing adopted children as persons who can receive the heirs of hearingmandatory wills, endowments in cash, and so on. At present, changes have taken place in various other fields due to the advancement of technology, information,

${ }^{32}$ Munawir Haris, "Pembaharuan Atas Hukum Keluarga di Indonesia: Satu Tinjauan Sosiologis", Ulumuna, Vol. 19, No. 1, 2015, p. 150-156. 
industry and in various other fields of science. This encourages the state to regulate it in legislation so that chaos does not occur. ${ }^{33}$

The renewal of Islamic law is an attempt to harmonize the understanding and application of Islamic teachings in the field of law with modern advancements while remaining based on Islamic teachings. The purpose of reforming Islamic family law, in general, can be grouped as follows: 1) Unification of marriage law. 2) Increased female status. 3) Response to the development and demands of the times. 4) Providing legal certainty for marital matters. 5) Become the judge's grip. ${ }^{34}$

Reformation of Islamic family law there are at least three typologies to map Muslim countries in carrying out family law reforms, namely: first, Muslim countries that do not want to make reforms and still enforce family law as stipulated in the fiqh books of the school of faith like Saudi Arabia. Secondly, Muslim countries that have entirely abandoned Islamic family law and instead took European Civil law such as Turkey. Third, the Islamic state that seeks to enforce Islamic family law but is implementing reforms here and there like Jordan, Indonesia. $^{35}$

Concerning the process of reformulating figh in the form of a Law as seen in Law No. 1 of 1974, it can be sorted into four possibilities, namely: first, the Law has wholly followed the fiqh munakahat. It even seems to quote directly from AlQuran is an example of the provisions regarding the prohibition of marriage and the provisions regarding the period of iddah for a divorced wife from her husband, which is then spelled out in government regulations. Secondly, the provisions contained in the Law are not included in the fiqh munakahat any school of thought

\footnotetext{
${ }^{33}$ Muhammadong, "Dinamika Pembaharuan Hukum Islam di Indonesia dan Tantangannya", Sulesana, Vol. 8, No. 2, 2013, p. 86.

${ }^{34}$ M. Nur Hasan Latief, "Pembaharuan Hukum Keluarga Serta Dampaknya Terhadap Pembatasan Usia Minimal Kawin dan Peningkatan Status Wanita", Jurnal Hukum Novelty, Vol. 7, No. 2, 2016, p. 197.

${ }^{35}$ Muhammadong, op.Cit., p. 81.
} 
because it is administrative and not substantial can be added to the fiqh as a record of marriage and marriage prevention. Third, the provisions in the Law are not found in the fiqh books of various schools, but due to the consideration of the benefit of these provisions can be accepted such as the minimum age limit of the prospective spouse to marry and the provisions of joint property in marriage. Fourth, the provisions contained in the Law outwardly appear to contradict the provisions of fiqh munakahat in various schools but by using reinterpretation, and considering the benefit of these provisions can be accepted. The intended provisions, such as the requirement for divorce before the court and the requirement for polygamy permit by the court and divorce, must be based on the reasons specified in the Act. ${ }^{36}$

\section{Conclusion}

The rearrangement and dynamication of family law in Indonesia, when viewed in the context of Islamic law reform, presents a unique and problematic portrait of reform. It is said so because Indonesia applies three legal systems, namely customary law, Islamic law, and Western law. Aspects related to the renewal of family law in Indonesia include: methodological aspects, social aspects, and material aspects. The process of reformulating fiqh into the form of an Act can be seen in Law Number 1 of 1974, then it can be divided into four possibilities, namely: First, the Law has wholly followed the fiqh munakahat and even seems to quote directly from the Al-Quran; Secondly, the provisions contained in the Law are entirely absent from the fiqh munakahat any school of thought because they are administrative rather than substantial can be added to fiqh as marriage registration and marriage prevention; Third, the provisions in the Act are not found in the fiqh books of various schools but because of consideration of the benefit of these

${ }^{36}$ Nor Salam, 2013, Pembaruan hukum keluarga Islam di Indonesia melalui putusan Mahkamah Konstitusi: Studi kasus putusan MK Nomor 46/PUU-VIII/2010, Tesis, Universitas Islam Negeri Maulana Malik Ibrahim, Malang, p. 31-34. 
provisions can be accepted; and Fourth, the provisions contained in the Act outwardly appear to contradict the provisions of fiqh munakahat in various schools but by using reinterpretation and considering the benefit of these provisions can be accepted.

\section{References}

\section{Books}

Bisri, Cik Hasan, 1999, Kompilasi Hukum Islam dan Peradilan Agama Dalam Sistem Hukum Nasional, Logos, Jakarta.

Manan, Abdul, 2006, Reformasi Hukum Islam di Indonesia, Rajawali Pers, Jakarta.

Raharjo, Satjipto, 2009, Membangun dan Merombak Hukum Indonesia, Genta Publishing, Yogyakarta.

Rofiq, Ahmad, 1995, Pembaharuan Hukum Islam di Indonesia, Raja Grafindo Persada, Jakarta.

Syarifuddin, Amir, 2005, Meretas Kebijakan Isu-isu Penting Hukum Islam Kontemporer di Indonesia, Ciputat Press, Jakarta.

Syaukani, Imam, 2006, Rekonstruksi Epistemologi Hukum Islam dan Relevansinya dengan Pembangunan Hukum Nasional, Raja Grafindo Persada, Jakarta.

\section{Journals}

Bancin, Ratih Lusiani, "Hukum Keluarga Islam di Tunisia", Jurnal: Penelitian Medan Agama, Vol. 9, No. 2, 2018.

Barkah, Qodariah, "Kebijakan Kriminalisasi Dalam Reformasi Hukum Keluarga Di Indonesia", Nurani, Vol. 17, No. 1, 2017.

Cahyani, A. Intan, 2016, "Pembaharuan Hukum Dalam Kompilasi Hukum Islam", ad-Daulah, Vol. 5, No. 2.

Gusminalita, Yessy, Doli Witro, and Kesi Afrilia, "Education Child In A Family Of Surah An-Nisa' Verse 9 Perspective”, PIONIR: Jurnal Pendidikan, Vol. 9, No. 1, 2020.

Haris, Munawir, "Pembaharuan Atas Hukum Keluarga di Indonesia: Satu Tinjauan Sosiologis", Ulumuna, Vol. 19, No. 1, 2015. 
Latief, M. Nur Hasan, "Pembaharuan Hukum Keluarga Serta Dampaknya Terhadap Pembatasan Usia Minimal Kawin dan Peningkatan Status Wanita", Jurnal Hukum Novelty, Vol. 7, No. 2, 2016.

Muhammadong, "Dinamika Pembaharuan Hukum Islam di Indonesia dan Tantangannya", Sulesana, Vol. 8, No. 2, 2013.

Munawarah, Lathifah, "Politik Hukum Keluarga Islam di Tunisia", Jurnal Al- 'Adl, Vol. 12, No. 1, 2019.

Natardi, Ali Hamzah, dan Doli Witro, "Pemikiran Islam Kontemporer Tentang Reposisi Kesetaraan Gender dalam Perspektif Al-Quran", AL-MAIYYAH: Media Transformasi Gender dalam Paradigma Sosial Keagamaan, Vol. 13, No. 1, 2020.

Riadi, Holan, "Hukum Keluarga Islam di Indonesia dan Dinamikanya", Mukammil: Jurnal Kajian Keislaman, Vol. 1 No. 2, 2019.

Setiawan, Eko, "Dinamika Pembaharuan Hukum Keluarga Islam di Indonesia", De Jure: Jurnal Syariah dan Hukum, Vol. 6, No. 2, 2014.

Sidqi, Imaro and Doli Witro, "Kedudukan Fatwa Majelis Ulama Indonesia (MUI) Dalam Perspektif Hukum Islam dan Nasional: Studi Implikasi Fatwa Terhadap Masyarakat", Nizham, Vol. 8, No. 1, 2020.

Sulaeman, Budiman, “Asas-Asas Hukum Keluarga Dalam Kompilasi Hukum Islam (Membedah Pasal-Pasal Khi)”, Jurnal Hukum Diktum, Vol. 9, No. 2, 2011.

Syahril, Sulthan, "Munawir Syadzali (Sejarah Pemikiran Dan Kontribusinya Bagi Perkembangan Pemikiran Islam Indonesia Kontemporer)", Analisis, Vol. 11, No 2, 2011.

Witro, Doli, "Islamic Religious Education In The Family To Strengthen National Resilience Of Surah At-Tahrim Verse 6 Perspective", Al-Muaddib :Jurnal Ilmu-Ilmu Sosial dan Keislaman, Vol. 4, No. 2, 2019.

Witro, Doli, "Kelompok Wanita Tani (KWT) Pelangi Kopi Sebagai Inovasi Pemberdayaan Janda Guna Mengentaskan Kemiskinan di Desa Giri Mulyo", Komunitas: Jurnal Pengembangan Masyarakat Islam, Vol. 10, No. 2, 2019. 
Witro, Doli, "Praktek Jual Beli Parang dengan Cara Penumpukan untuk Meningkatkan Harga di Desa Koto Padang Perspektif Hukum Islam”, AlQisthu, Vol. 17, No. 1, 2019.

Witro, Doli, "Ulama and Umara in Government of Indonesia: a Review Relations of Religion and State", Addin, Vol. 14, No. 1, 2020.

Witro, Doli, "Urgency Building Islamic Economic System In Indonesia Al-Quran Perspective", Jurnal Ekonomi Islam, Vol. 11, No. 1, 2020.

Witro, Doli, Ike Yulisa, and Ali Hamzah, "Management Of Productive Waqf In Islamic Boarding School Foundation Adlanyah Tampus Ujung Gading Lembah Melintang District”, Mahkamah: Jurnal Kajian Hukum Islam, Vol. 5, No. 1, 2020.

Yusuf, Muhamad, Doli Witro, Rahmi Diana, Tomi Apra Santosa, Annisa "Alwiyah Alfikri, and Jalwis, "Digital Parenting to Children Using The Internet". Pedagogik Journal of Islamic Elementary School, Vol. 3, No. 1, 2020.

\section{Research}

Nor Salam, 2013, Pembaruan hukum keluarga Islam di Indonesia melalui putusan Mahkamah Konstitusi: Studi kasus putusan MK Nomor 46/PUUVIII/2010, Tesis, Universitas Islam Negeri Maulana Malik Ibrahim, Malang.

\section{Internet}

Fitri, Al, Pembaruan Hukum Keluarga di Indonesia Melalui Kompilasi Hukum Islam, https://badilag.mahkamahagung.go.id/, accessed on 20 April 2020. 